\title{
Environmental Sanitation Relationship With Diarrhea Incidence In The Village Of Kaofe Kadatua Subdistrict Buton County
}

\author{
Anwar Mbolosi \\ Public Health Undergraduate Study Program, Faculty of Health Sciences, UIN Alauddin Makassar
}

ARTICLE INFO

Keywords:

Quality of Health Services, Interest in Re-Visits, Health Centers

E-mail: anwarmbolosi17@gmail.com
ABSTRACT

Diarrhea is a disease characterized by an increase in the frequency of bowel movements more than usual (usually this frequency is more than three times per day) accompanied by changes in the shape and consistency of stool, vomiting, vomiting or usually once a day but characterized by mucus or blood. Diarrhea is still a public health problem, several factors that cause diarrheal disease are caused by germs through contamination of food or drink contaminated with feces and or direct contact with sufferers, while other factors include host and environmental factors. This study aims to determine the relationship between environmental sanitation and the incidence of diarrhea in the people of Kaofe Village, Kadatua District, Buton Regency in 2010. This type of research is an analytical survey research. The population in this study were all heads of families in Kaofe Village, the number of samples studied was 157 samples. The data collection technique was by random sampling which was equipped with a questionnaire to determine the relationship between environmental sanitation (providing clean water, providing family latrines, managing solid waste, managing liquid waste) with the incidence of diarrhea. The data were processed using SPSS 16.0 and presented in the form of a frequency distribution table and an analysis between variables which was accompanied by an explanation. The results showed that there was a relationship between the provision of clean water and the incidence of diarrhea with a value of $\mathrm{P}=0.000$, there was a relationship between the provision of family latrines and the incidence of diarrhea with a value of $\mathrm{P}=0.001$, there was no relationship between solid waste management and the incidence of diarrhea $\mathrm{P}=0.296$, there is a relationship between liquid waste management and the incidence of diarrhea with a value of $P=0.003$. Seeing the high incidence of diarrhea in the people of Kaofe Village, Kadatua District, it is suggested to the community to improve environmental sanitation by improving clean water facilities, having latrines that meet the requirements, and having SPAL that meets the requirements.

Copyright (C) 2021 Eduhealth Journal.All rights reserved. is Licensed under a Creative Commons AttributionNonCommercial 4.0 International License (CC BY-NC

4.0)

\section{INTRODUCTION}

The Relationship between Environmental Sanitation and Diarrhea in the Community of Kaofe Village, Kadatua District, Buton Regency, Anwar Mbolosi 
One indicator of the success of national development is the increase in health status. The health status of a country can be measured by looking at the level of morbidity and mortality rates caused by age and life expectancy. The National Health System (SKN) has formulated one of the national development goals, namely the achievement of the ability to live a healthy life[1]. Based on the foregoing, one way to achieve this is by monitoring and controlling disease[2]. The health conditions of individuals and communities can be influenced by environmental conditions. Poor environmental quality is the cause of various disturbances to public health. To achieve optimum public health status, an optimum environmental condition or condition is needed[3].

Diarrhea is still a public health problem, several factors that cause diarrheal disease are caused by germs through contamination of food or drink contaminated with feces and or direct contact with sufferers, while other factors include host and environmental factors. According to the results of the Household Health Survey (SKRT) in 2004, the death rate from diarrhea was 23 per 100 thousand population and 75 per 100 thousand children under five. The high incidence of diarrhea is understandable due to poor environmental sanitation conditions, especially in densely populated areas, where poor environmental sanitation is an important factor in the transmission of diarrheal disease in addition to other factors such as nutritional status, socioeconomic status, education, community behavior and etc[4]. Improving environmental sanitation is an effort to improve the human environment so that it becomes a good medium for the realization of optimum health for humans in it[5]. UU no. 23 of 1992 concerning health states that "Environmental health is held to realize the degree of public health which can be done, among others, through environmental sanitation"[6].

The dominant factor causing diarrhea is clean water and faecal disposal facilities (Buton District Health Office). Disposal places for waste, waste water, and feces that do not meet health requirements can cause low water quality, and can cause various kinds of infectious diseases (Buton Health Office). In Buton Regency the diarrhea morbidity rate for all age groups based on the SP2TP report of the Buton Regency health office was 10,546 people, 18 people died, while in the Kadatua Health Center the diarrhea morbidity rate for all age groups was 958 people, 2 people died, while in Kaofe Village itself has a diarrhea morbidity rate in 2009 is 130 people and is the village with the most cases of diarrhea cases among all villages in Kadatua District. In Buton district, the number of household heads (KK) who use clean water facilities that meet the requirements is $81.24 \%$ of the 6695 households examined, who have family latrines $51.4 \%$ of the 93611 households inspected, $49.7 \%$ of 1879 households to store garbage KK inspected and waste water disposal facilities that meet the requirements $19.4 \%$ of the 93611 inspected. For the Kaofe village area, the coverage of family heads using clean water is $68 \%$, family latrines are $54.07 \%$, trash cans are $57 \%$ and waste water disposal facilities are $20.09 \%$. Based on the description above, where the coverage of environmental sanitation is still low and the incidence of diarrhea is high and the working area of the puskesmas is an area of diarrhea incidence.

In Indonesia, the high prevalence of infectious diseases is strongly influenced by the state of the physical, biological, social environment, such as diseases caused by bacteria, viruses and parasites which generally thrive in a humid and dirty tropical climate. The high rate of population growth and urbanization also affects the quality of the living environment and tends to cause a high danger of pollution, limited supply of drinking water and an increase in the amount of waste, waste water, human waste produced and the lack of cleanliness of the residential environment is the driving force for various diseases.[7].

The indirect effect of water on health is the effect arising from the utilization of water that can increase or decrease the welfare of the community. For example, water is used for industry, power generation, agriculture and others. On the other hand, water pollution can reduce people's welfare. contamination of water bodies with chemicals that can reduce dissolved oxygen levels, non-toxic chemicals that are difficult to decompose naturally and cause special problems such as aesthetics, turbidity due to suspended matter. The direct effect of water on health on health depends very much on water quality and occurs because water functions as a distributor or as a disseminator of diseasecausing insects or as a nest of disease-spreading insects.[8]. As for the causes of disease in water, it can cause direct effects on health, such as Cholera disease by Vibrio Cholerae bacteria, and Minamata disease due to Mercury poisoning.

The Relationship between Environmental Sanitation and Diarrhea in the Community of Kaofe Village, Kadatua District, Buton Regency, Anwar Mbolosi 
A family latrine is a building used to dispose of human waste or feces, commonly called a latrine or toilet[9]. Disposal of feces that do not meet health requirements will cause contamination of ground water. Family latrines have the main function as a place to isolate human waste (feces). The goal is to isolate feces so that flies and other animals cannot enter and breed. The types of latrines are adapted to regional conditions and socio-economic levels as well as the needs of the community itself.

It is known that waste is a direct consequence of life, so it can be said that waste has arisen since human life[10]. The emergence of togetherness with human activities starting from the addition/taking of natural resources as raw materials, continues to become materials that are ready for energy, semi-finished materials for goods and service activities. In developing countries, it is estimated that $30-50 \%$ of solid waste generated from urban centers will remain uncollected. Garbage that is scattered on the streets and at home, will encourage serious health problems[11]. Residential areas inhabited by poor people will be more susceptible to disease because of the lack of adequate waste collection facilities.

\section{METHOD}

One of the efforts made to reduce morbidity and mortality due to diarrhea is the improvement of basic sanitation. According to Cjetanofik et al stated that intensive and continuous improvement of sanitation for 10 years can reduce diarrhea morbidity by $\pm 50 \%$ compared to vaccination or cure with drugs.

The independent variables in this study were: Clean Water Utilization, provision of family latrines, waste storage areas and waste water disposal facilities. The dependent variable, in this case is the incidence of diarrhea.

The Operational Definitions and Objective Criteria used are

a. Provision of clean water is water used by the head/family member in meeting their daily needs.

Operational definition Qualify

Not eligible

\section{Information}

if the water is clear, colorless, odorless and tasteless, it is stored in a closed container and the distance from the water source to the source of pollution is 10 meters.

if it does not meet the criteria above.

b. Provision of family latrines is a place used by the head and family members to dispose of feces that meet health requirements.

Operational definition Qualify

\section{Information}

if it has a catchment hole and is convex in shape with a cover or in the shape of a goose neck, it is used and cleaned at least twice a week.

if it does not meet the criteria above.

Not eligible

ste) is a means to store temporary waste that meets the requirements

c. Solid waste management (waste) is a means to store temp
before the waste is disposed of in the final disposal site.

Operational definition Qualify

\section{Information}

has a temporary waste storage area, the place has a cover, is cleaned at least once a week, is kept clean and if the waste is disposed of in a final disposal place the distance from the water source is 10 meters

Not eligible if it does not meet the criteria above.

d. Liquid waste management is a means of disposing of household waste water in the form of canals, shelters originating from the kitchen, laundry, and bathroom owned by the respondent.

Operational definition Qualify

Not eligible
Information

if it has a hole and has a cover, has a channel and the water is smooth, the distance from the waste water reservoir to the drinking water source is 10 meters.

if it does not meet the criteria above. 
e. The incidence of diarrhea is a symptom of a disease characterized by an increase in the frequency of defecation more than three times per day with changes in the shape of the stool to become watery, watery and usually pale white in color, mixed with blood.

Operational definition Suffer

No Suffering

The population of this study was all heads of families (KK) in the Kaofe village area, totaling 260 households. The sample in this study is the head of the selected family in the village of Kaofe. Determination of the sample was selected by random sampling. Data were collected by means of interviews using a house-to-house questionnaire. Data obtained from the Health Office, Puskesmas, village offices and related agencies with the object of research.

\section{RESULTS AND DISCUSSION}

3.1 Descriptive Analysis

Table 1 Distribution of Respondents by Age Group in the Kaofe Village Community, Kadatua District, Buton Regency

\begin{tabular}{ccc} 
Respondent's age & $\mathbf{n}$ & $\mathbf{\%}$ \\
\hline $21-25$ & 12 & 7.6 \\
$26-30$ & 19 & 12.1 \\
$31-35$ & 17 & 10.8 \\
$36-40$ & 20 & 12.7 \\
$41-45$ & 24 & 15.3 \\
$46-50$ & 18 & 10.8 \\
$>50$ & 48 & 30.6 \\
\hline Amount & 157 & 100
\end{tabular}

Table 2 Distribution of Respondents according to the incidence of diarrhea in the people of Kaofe Village, Kadatua District, Buton Regency

\begin{tabular}{lcc}
\multicolumn{1}{c}{ dare incident } & n & \% \\
\hline Suffer & 65 & 41.4 \\
Not suffering & 92 & 58.6 \\
\hline amount & 157 & 100
\end{tabular}

Based on table 2, from 157 respondents there were 65 respondents with diarrhea or $41.4 \%$ and 92 respondents who did not suffer or $58.6 \%$.

\begin{tabular}{lcc}
\multicolumn{1}{r}{ Age group (years) } & n & \% \\
\hline 20 & 49 & 31.2 \\
$21-25$ & 6 & 3.8 \\
$26-30$ & 1 & 0.6 \\
$>40$ & 9 & 5.7 \\
\hline amount & 65 & 100
\end{tabular}

Table 3 shows the highest percentage of diarrhea sufferers in the age group under 20 years, namely 49 patients or $31.2 \%$, the least in the 26-30 age group, namely 1 patient or $0.6 \%$.

Table 4 Distribution of Respondents by Provision of Clean Water in the Kaofe Village Community,

Kadatua District, Buton Regency

\begin{tabular}{lcc}
\multicolumn{1}{c}{ Source of clean water } & $\mathbf{n}$ & $\mathbf{\%}$ \\
\hline PAH/ Rainwater Storage & 49 & 68.8 \\
dug well & 108 & 31.2 \\
\hline amount & 157 & 100
\end{tabular}

According to table 4, the highest percentage of respondents who use clean water is dug wells 108 respondents or $68.8 \%$ and the lowest is rainwater storage (PAH) which is 49 respondents or $31.2 \%$.

Table 5 Distribution of Respondents according to the Physical Requirements of Clean Water in the

Kaofe Village Community, Kadatua District, Buton Regency

Source of clean water

n $\%$

The Relationship between Environmental Sanitation and Diarrhea in the Community of Kaofe Village, Kadatua District, Buton Regency, Anwar Mbolosi 


\begin{tabular}{lcc} 
Qualify & 87 & 55.4 \\
Not eligible & 70 & 44.6 \\
\hline amount & 157 & 100
\end{tabular}

Table 5 shows that the physical percentage of clean water that meets the requirements is $55.4 \%$ and those who do not meet the requirements is $44.6 \%$.

Table 6 Distribution of Respondents by Provision of Family Toilets in the Community of Kaofe

Village, Kadatua District, Buton Regency

\begin{tabular}{lcc}
\multicolumn{1}{r}{ Family latrine } & n & \% \\
\hline Have & 88 & 56.1 \\
Do not have & 69 & 43.9 \\
\hline amount & 157 & 100
\end{tabular}

Table 6 shows that from 157 respondents there were 88 respondents who used family latrines or $56.1 \%$ and those who did not use family latrines 69 respondents or $43.9 \%$.

Table 7 Distribution of Respondents according to the Physical Requirements for Family Latrine in the Kaofe Village Community, Kadatua District, Buton Regency

\begin{tabular}{lcc}
\multicolumn{1}{r}{ Family latrine } & n & \% \\
\hline Qualify & 72 & 81.8 \\
Not eligible & 16 & 18.2, \\
\hline amount & 88 & 100
\end{tabular}

Table 7 shows that from 88 respondents who have family latrines, there are 70 units or $81.8 \%$ who meet the requirements and 16 units or $18.2 \%$ who do not meet the requirements.

Table 8 Distribution of Respondents by Ownership of Trash Cans in the Community of Kaofe Village, Kadatua District, Buton Regency

\begin{tabular}{lcc}
\multicolumn{1}{c}{ Rubbish bin } & $\mathrm{n}$ & $\%$ \\
\hline Have & 94 & 59.9 \\
Do not have & 63 & 40.1 \\
\hline amount & 157 & 100
\end{tabular}

Table 8 shows that respondents who use trash cans are 94 or $59.9 \%$ and respondents who do not use trash cans are 63 respondents or $40.1 \%$.

Table 9 Distribution of Respondents according to the Physical Requirements of Trash Cans in the Community of Kaofe Village, Kadatua District, Buton Regency

\begin{tabular}{lcc}
\multicolumn{1}{c}{ Rubbish bin } & $\mathrm{n}$ & $\%$ \\
\hline Qualify & 54 & 57.4 \\
Not eligible & 40 & 42.6 \\
\hline amount & 94 & 100
\end{tabular}

Based on table 9 of the 94 respondents who used the trash can, 54 or $57.4 \%$ met the requirements and 40 or $42.6 \%$ did not meet the requirements.

Table 10 Distribution of Respondents by Ownership of SPAL in the Kaofe Village Community, Kadatua District, Buton Regency

\begin{tabular}{|c|c|c|}
\hline SPAL & $\mathbf{n}$ & $\%$ \\
\hline Have & 65 & 41.4 \\
\hline Do not have & 92 & 58.6 \\
\hline amount & 157 & 100 \\
\hline
\end{tabular}

Table 10 shows that 65 respondents who use waste water disposal facilities or $41.4 \%$ and 92 respondents who do not use or $58.6 \%$.

Table 11 Distribution of Respondents according to SPAL Physical Requirements in the Kaofe Village Community, Kadatua District, Buton Regency

\begin{tabular}{|c|c|c|}
\hline SPAL & n & $\%$ \\
\hline Qualify & 44 & 67.7 \\
\hline Not eligible & 21 & 32.3 \\
\hline amount & 65 & 100 \\
\hline
\end{tabular}

The Relationship between Environmental Sanitation and Diarrhea in the Community of Kaofe Village, Kadatua District, Buton Regency, Anwar Mbolosi 
Based on the results of research from 65 respondents who use waste water disposal facilities (SPAL) there are 44 units $(67.7 \%)$ that meet the requirements and 21 units $(51.5 \%)$ who do not meet the requirements.

\subsection{Analysis of Relationship Between Variables}

In this variable analysis, an analysis of the relationship between the provision of clean water, the provision of family latrines, solid waste management facilities and liquid waste management facilities was carried out with the incidence of diarrhea in the people of Kaofe Village, Kadatua District, Buton Regency.

Table 12 Relationship between clean water supply and diarrhea incidence in the community of Kaofe Village, Kadatua District, Buton Regency

\begin{tabular}{|c|c|c|c|c|c|c|c|}
\hline \multirow{3}{*}{ Clean water } & \multicolumn{4}{|c|}{ Diarrhea } & \multirow{2}{*}{\multicolumn{2}{|c|}{ Total }} & \multirow{3}{*}{$\mathbf{P}$} \\
\hline & & ring & & & & & \\
\hline & $\mathbf{n}$ & $\%$ & $\mathbf{n}$ & $\%$ & $\mathbf{n}$ & $\%$ & \\
\hline qualify & 68 & 78.2 & 19 & 21.8 & 87 & 100 & 0.000 \\
\hline Not eligible & 24 & 34.3 & 46 & 65.7 & 70 & 100 & \\
\hline
\end{tabular}

Based on table 12 above, it can be seen that of the 65 samples suffering from diarrhea 19 $(21.8 \%)$ whose clean water supply met the requirements and $46(65.7 \%)$ did not meet the requirements, while from 92 samples that did not suffer from diarrhea there were 68 (65.7\%) 78.2\%) whose clean water supply meets the requirements and $24(34.3 \%)$ whose clean water supply does not meet the requirements. Based on the calculation of statistical analysis, the value of $\mathrm{P}=(0.000)<0.05$ means that this test is said to be meaningful.

Table 13 Relationship between the provision of family latrines with the incidence of diarrhea in the people of Kaofe Village, Kadatua District, Buton Regency

\begin{tabular}{|c|c|c|c|c|c|c|c|}
\hline \multirow{3}{*}{ Family Toilet } & \multicolumn{4}{|c|}{ Diarrhea } & \multirow{2}{*}{\multicolumn{2}{|c|}{ Total }} & \multirow{3}{*}{$\mathbf{P}$} \\
\hline & \multicolumn{2}{|c|}{ Not suffering } & \multicolumn{2}{|c|}{ suffer } & & & \\
\hline & $\mathbf{n}$ & $\%$ & $\mathbf{n}$ & $\%$ & $\mathbf{n}$ & $\%$ & \\
\hline qualify & 53 & 73.6 & 19 & 26.4 & 72 & 100 & \\
\hline Not eligible & 39 & 45.9 & 46 & 54.1 & 85 & 100 & 0.001 \\
\hline
\end{tabular}

Based on table 13 above, it can be seen that of the 65 samples suffering from diarrhea there were 19 (26.4\%) whose family latrine provision met the requirements and $46(54.1 \%)$ did not meet the requirements, while of the 92 samples who did not suffer from diarrhea there were $53(73.6 \%)$ whose family latrines meet the requirements and 39 (45.9\%) whose family latrines do not meet the requirements. Based on the calculation of statistical analysis, the value of $\mathrm{P}=(0.001)<0.05$ means that this test is said to be meaningful.

Table 14 Relationship between Solid Waste Management and Diarrhea in the Community of Kaofe Village, Kadatua District, Buton Regency

\begin{tabular}{lccccccc}
\multicolumn{1}{c}{$\begin{array}{c}\text { Solid Waste } \\
\text { Management }\end{array}$} & \multicolumn{4}{c}{$\begin{array}{c}\text { Diarrhea } \\
\text { Not suffering }\end{array}$} & \multicolumn{2}{c}{ suffer } & \multicolumn{2}{c}{ Total } & \multirow{2}{*}{ P } \\
& n & $\mathbf{\%}$ & n & \% & n & \% & \\
\hline qualify & 37 & 64.9 & 20 & 35.1 & 57 & 100 & \multirow{2}{*}{0.296} \\
Not eligible & 55 & 55.0 & 45 & 45.0 & 100 & 100 &
\end{tabular}

Based on table 14 above, it can be seen that of the 65 samples suffering from diarrhea, 20 (35.1\%) whose solid waste management met the requirements and

$45(45.0 \%)$ did not meet the requirements, while of the 92 samples that did not suffer from diarrhea there were $37(64.9 \%)$ whose solid waste management met the requirements and $55(55.0 \%)$ whose solid waste management did not meet the requirements. Based on the calculation of statistical analysis, the value of $\mathrm{P}=(0.296)>0.05$ means that this test is said to be meaningless.

Table 15 Relationship between Wastewater Management (SPAL) and the incidence of diarrhea in the people of Kaofe Village, Kadatua District, Buton Regency

\begin{tabular}{lllll}
$\begin{array}{l}\text { Liquid Waste } \\
\text { Management }\end{array}$ & Not suffering & suffer & Total & P \\
\hline
\end{tabular}




\begin{tabular}{lccccccc} 
& n & \% & n & \% & n & \% & \\
\hline qualify & 37 & 77.1 & 11 & 22.9 & 48 & 100 & \multirow{2}{*}{0.003} \\
Not eligible & 55 & 50.5 & 54 & 49.5 & 109 & 100 &
\end{tabular}

Based on table 15 above, it can be seen that of the 65 samples suffering from diarrhea 11 $(22.9 \%)$ whose wastewater management met the requirements and $54(49.5 \%)$ did not meet the requirements, while of the 92 samples that did not suffer from diarrhea there were 37 (49.5\%) $77.1 \%$ ) whose liquid waste management meets the requirements and $54(49.5 \%)$ whose liquid waste management does not meet the requirements. Based on the calculation of statistical analysis, the value of $\mathrm{P}=(0.003)<0.05$ means that this test is said to be meaningful.

\subsection{Discussion}

Healthy drinking water must contain certain substances in certain amounts. Lack or excess of one of the chemicals in the water, will cause physiological disturbances in humans. Based on the results of the study showed that respondents who used drinking water sources that met the requirements did not get diarrhea as many as 68 respondents $(78.2 \%)$, while those who had diarrhea were 19 respondents $(26.4 \%)$, while respondents whose drinking water sources did not meet There are 26 respondents $(15.3 \%)$ who do not suffer from diarrhea, while 46 respondents $(29.3 \%)$ have diarrhea. From the results of the bivariate test, the value of $\mathrm{P}=0.000(\mathrm{p}<0.05)$. Thus it can be concluded that $\mathrm{Ho}$ is rejected and $\mathrm{Ha}$ is accepted, so that there is a relationship between drinking water sources (clean water supply) and the incidence of diarrhea in the people of Kaofe Village, Kadatua District, Buton Regency. Based on the results of the questionnaire, the dominant source of drinking water in the Kaofe Village community is dug wells by 108 respondents and is the main water source and the rest is PAH as many as 49 respondents. A good well must meet health requirements, among others, the distance from the well to the latrine hole, the distance from the well to the waste dug hole, waste water disposal channels, and other sources of impurities. The distance between the well and the sewage disposal site is preferably 10 meters or more. Based on the results of interviews with respondents, for family drinking purposes, the mother first cooks drinking water until it boils. Drinking water that has been boiled until it boils, will kill the microorganisms in the water, so it does not cause disease. For drinking and cooking purposes, some people collect the water in water reservoirs, but there are some respondents who do not first boil the water taken from the well but they directly consume the water or store it in a reservoir, they consider water that is not cooked beforehand is not dangerous and can be drunk directly, because there are still many people who think that clean water definitely meets the requirements, they do not know that clean water cannot be drunk directly but must be cooked first, even though the water is clear but bacteriologically the water does not necessarily meet the requirements.

Based on the results of the study, it can be seen that from 157 samples, $65(41.4 \%)$ had diarrhea and $92(58.6 \%)$ did not suffer from diarrhea, each of which was distributed as follows: from 65 samples with diarrhea $19(29,2 \%)$ whose family latrine use met the requirements and $46(70.8 \%)$ did not meet the requirements, while from the 92 samples that did not suffer from diarrhea there were 53 $(57.6 \%)$ whose family latrine provision met the requirements and $39(42.4 \%)$ whose family latrines do not meet the requirements. From the results of the bivariate test, the value of $p=0.001(p<0.05)$. Based on the results of interviews with respondents, it is known that there are still many people who do not have private latrines, so that when they defecate they ride in neighboring latrines, defecate in the sea near the house because of the condition of the village of kaofe which is near the sea. Then for people who do not have latrines, it will indirectly cause other problems, for example the feces of their children and toddlers will be thrown into the sea, or to the yard near their house because of their limitations in not having a latrine. They still think that the feces of children and toddlers are harmless.

Based on the results of research and field observations, it was found that the number of respondents who used the trash can was 93 respondents or $(59.9 \%)$, while those who did not use the trash were 64 respondents or $(41.1 \%)$. The respondents who use the trash can are 54 respondents who have a trash can that meets the requirements where the trash can has a cover, does not leak and is always cleaned, while respondents who have a trash can and do not meet the requirements are 39 respondents. The researcher found that in the Kaofe Village community the condition of solid waste 
management was quite good which was obtained from statistical tests in the field there was no significant relationship between solid waste management and the incidence of diarrhea in the community.

Based on the results of research conducted on the people of Kaofe Village, the management of liquid waste found that the management of liquid waste with a higher percentage of diarrhea sufferers than the management of liquid waste that meets the requirements. In the Kaofe Village community in general, the research sample is many who do not meet the requirements because most household wastewater disposal does not have a special channel, it is just dumped under the house or next to the house so it is very likely that diarrheal disease is easily infected in the area caused by disease vector. The researcher found that in the Kaofe village community the incidence of diarrhea was quite high so that the results obtained in the statistical test in the field there was a significant relationship between liquid waste management and the incidence of diarrhea in that community. The results showed that the use of family latrines affected the occurrence of diarrhea with $\mathrm{P}$ value $=0.021<0.05$. In terms of health, the problem of managing household wastewater in rural areas needs considerable attention. Disposal of household waste water that is not managed properly can cause harmful things, among others, can pose a danger of contamination of surface water sources and other water sources including water used by humans for daily purposes such as bathing, brushing teeth, and especially drinking water. In general, the people of Kaofe Village, the sewerage is not qualified because most of the wastewater is not flowing, inundated and the distance of the water source with the sewerage of wastewater is not so far so that the transmission of diseases through vectors such as flies that carry pathogenic microorganisms by not covering the food served so that flies until eaten and when eaten someone can get diarrhea.

\section{CONCLUSION}

Based on the results of the research conducted, it was concluded that there was a significant relationship between the provision of clean water and the incidence of diarrhea in the people of Kaofe Village. Kaofe Village, because people whose family latrines meet the requirements tend not to get diarrhea, there is no significant relationship between solid waste management and the incidence of diarrhea in the Kaofe Village community and there is a significant relationship between liquid waste management and diarrhea, because people who manage waste Liquids that meet the requirements are less likely to get diarrhea.

\section{REFERENCES}

[1] Kementerian Kesehatan Indonesia, Profil Kesehatan Indonesia Tahun 2019, vol. 42, no. 4. 2019.

[2] R. Kemenkes, pusat kesehatan indonesia. 2019.

[3] Kemenkes, Indonesian Health Profile 2019. 2019.

[4] PERPRES, Peraturan Presiden (PERPRES) tentang Sistem Kesehatan Nasional. 2012.

[5] D. Soni, S. Suryana, and H. K. Herdianty, "OPTIMASI PELARUT PENGEKSTRAKSI TEMPLATE MIP (MOLECULAR IMPRINTED POLIMER) FENILBUTAZON DENGAN MONOMER ASAM METAKRILAT," J. Ilm. Farm. Bahari, vol. 11, no. 2, 2020, doi: 10.52434/jfb.v11i2.794.

[6] BPJS Kesehatan, "Sejarah Perjalanan Jaminan Sosial di Indonesia," BPJS Kesehatan, 2020. .

[7] W. Wulandari, F. R.-A. J. Ilmiah, and undefined 2019, "Hubungan Sanitasi Lingkungan Dan Riwayat Penyakit Infeksi Dengan Kejadian Stunting Di Wilayah Kerja Puskesmas Kerkap," Core.Ac.Uk, 2020.

[8] F. Hasan and A. Ruhban, "HUBUNGAN SANITASI DASAR DENGAN KEJADIAN PENYAKIT DIARE DAN PENYAKIT KULIT DI HUNIAN SEMENTARA PASCA BENCANA KELURAHAN LERE, KECAMATAN PALU BARAT, KOTA PALU," Sulolipu Media Komun. Sivitas Akad. dan Masy., vol. 20, no. 2, 2020, doi: 10.32382/sulolipu.v2i20.1754.

[9] M. K. Fitrizah, "HUBUNGAN PENYEDIAAN AIR BERSIH DAN PENGGUNAAN JAMBAN DENGAN KEJADIAN DIARE PADA BALITA DI PUSKESMAS PASAR IKAN KOTA BENGKULU," Mitra Raflesia (Journal Heal. Sci., vol. 10, no. 2, 2020, doi: 10.51712/mitraraflesia.v10i2.11.

The Relationship between Environmental Sanitation and Diarrhea in the Community of Kaofe Village, Kadatua District, Buton Regency, Anwar Mbolosi 
[10] I. D. Marjuni and S. Lasmi, "HUBUNGAN KONDISI SARANA SANITASI LINGKUNGAN DENGAN KEJADIAN DIARE DI LEMBAGA PERMASYARAKATAN PEREMPUAN KELAS II A SUNGGUMINASA," Sulolipu Media Komun. Sivitas Akad. dan Masy., vol. 20, no. 1, 2020, doi: 10.32382/sulolipu.v20i1.1460.

[11] T. Ginting and S. Hastia, "Hubungan Sanitasi Lingkungan Dan Personal Hygiene Ibu Dengan Kejadian Diare Pada Balita di Kelurahan Sidorejo Puskemas Sering," J. Prima Med. Sains, vol. 1, no. $1,2019$. 